UDK 378

I. Zvarych, Doctor of Sciences (Pedagogy)

Kyiv National University of Trade and Economics, Kyiv, Ukraine N. Prymachenko, Ph.D.(Pedagogy) Drohobych Ivan Franko State Pedagogical University, Drohobych, Ukraine I. Romashchenko, Ph.D.(Pedagogy), Associate Professor Tavriya Volodymyr Vernadskiy National University, Kyiv, Ukraine

\title{
THE FUTURE TEACHER OF TECHNOLOGY IS A MORAL AND CULTURAL PERSONALITY IN THE EDUCATIONAL AND UPBRINGING APPROACHES OF EDUCATION
}

The article deals with the main ideas and principles of the problem under investigation; outlines the main professional abilities and competencies and implementing the methodological support into the educational process, which contributes to the effective formation of moral culture among future teachers of technology. According to leading scientists, the orientation of the higher school to the modern and even advanced level of development the socio-industrial relations in the specialists' training is possible only subject to the study of these requirements, because of the study of this specialist. The search for improvement of the professional training of the future teacher is a problem, the urgency of which is conditioned by the tendency of the requirements for the professional activity of the teacher.

The modern education of Ukraine is aimed at providing the students with the necessary knowledge, development of skills and abilities. During the training period, the future teacher should submit a lot of factual material. It is necessary to highlight the economic knowledge of most graduates of schools that have a theorized character, detached from reality, and, as a result, young people cannot resist the negative effects of a market economy. This is evidenced by the realities of the present; a part of the youth cannot be competitive in the labor market, due to lack of practical skills, moral and ethical education, the level of culture of communication and business etiquette of labor activity. In order to solve these tasks, an active implementation into the educational process of educational institutions, in particular pedagogical, disciplines of economic direction, is carried out. The researches show that a modern school needs teachers of technologies with a broad world outlook that possess not only a system of integrated knowledge of technological, psychological and pedagogical, methodical character, but also deep economic thinking. The establishments of higher education creating the cultural potential of the individual, designed to determine the way of its self-realization, the subjective content of its productive activities. Dependence of the level of formation and characteristics of the culture of the individual can vary in specific types and spheres of social life.

Keywords: a moral and cultural personality, an educational process, technology, a modern school, a leader, culture, an economic education, professional competence, competence, professional communication.

Formulation of the problem. The modernization of the educational system of Ukraine in the third millennium is aimed at the cultivation of a cultural person that meets the requirements of time and those processes that take place in the modern globalized world. The transition to a market economy determines the profound socio-economic changes in the state and reveals to the society an important pedagogical problem of the formation of entrepreneurship skills of young people, teaching to enter into life under current conditions and realities, and hence - an important transformation of the essence of education, especially the higher, the initial one. However, as evidenced by the analysis of practice, providing young people with purely economic knowledge do not solve the issue of their adaptation in the current dynamic socio-economic conditions. In our opinion, this economic knowledge is predominantly depressed and disconnected from real reality, resulting in the youth being unable to effectively counteract negative challenges in the era of globalization. Today, most young people are not well prepared for a changing labor market not only because of the lack of theoretical knowledge and practical skills.

Research objective is introducing the concept of educational and upbringing areas of education and identify the ways of implementation of this way directly in order to shape the moral culture of the future teachers of technology.

Analysis of recent researches and publications. The emergence and rise of the formation of moral culture of future teachers of technology, the preparation for the work of student and student youth, were highlighted in the works of famous scientists A.Vykhrushch, V.Oliynyk, M.Korets, V.Madzihon, Ye. Kulyk, O.Shpark, V. Tymenko, and others.

Research presentation. The development of education and science in Ukraine is inextricably linked with the history and rise of the Ukrainian nation and state. The formation of the Ukrainian nation took place in a considerable context of national processes, which traced both the intellectual aspects and inhibitions that influenced the national development of education and the quality of its management, the vocational training.
The educational process is systematic. The purpose of the current educational process of student in the process of formation the moral culture, is formulated by the harmony of social and individual goals, tasks, cooperation in their achievement.

Because of that, the socio-cultural processes, connected with the formation of the person' future memory, foreshadow a number of defining features, with the general logical direction to humanization of all human life branches. World perception of "culture" in its generally accepted thought carries the unique achievements of a person in the intellectual and mental spheres. Therefore, the process of integrating the depth of the mind, the will of power, the powers of the spirit becomes almost a priority task of the modern person. In this sense, the systemforming mechanisms of self-knowledge give the individual a universal opportunity to creative self-realization.

In their science works, the scholars have addressed such issues as the organization of educational and edifying functions to strengthen the role of the teacher as the leader of the process of socialization during the educational activities, in the process of studying, upbringing and development of cognitive interests and needs.

In the course of the study, we have determined that at the present stage it becomes more obvious that the traditional school is oriented on the transfer of knowledge, skills and abilities, does not keep pace with the rhythms of their build-up. The current school does not sufficiently develop the abilities needed by its graduates in order to independently self-identify in the world, to make weighty decisions about their future. The main drawbacks of the traditional system of education are the inability and unwillingness of young people to study constantly, lack of the formation of value attitudes towards their own development and education.

History shows that the dreams of humanity about the improvement of society are organically intertwined with thoughts on the improvement of labor education, and at the present time, it is a youth curriculum to work in a market economy. The millennial practice has given the chance to take the best ways to influence the person in order to 
succeed in moral and psychological and practical preparation for independent work life.

Preparing the young people for work in a market economy requires the significant changes in the economic education and schooling. This is the study of the foundations of the economy, the development of information and communication technologies, entrepreneurship, marketing and other disciplines, which form the professional competence of future specialist, and high professional skills.

Taking into consideration that the professional excellence is the goal and result of professional development and professional competence can be revealed as the level of skill that a person obtains on the path of professional development, gaining professionalism. The professionalism and skill of the future teacher of the educational and edifying directions of education in our research is based, first of all, on the professional competence, its contents content with qualitative knowledge, which depends on many factors: the level of development of psychology, pedagogy, anthropology and cultural studies, the social and economic reasons, which varies according to the processes taking place in education and society.

In the course of studying this problem, we have defined the interpretation of the concept "competence". In broad sense, competence is understood as the degree of maturity of a person who considers the true level of mental development of personality (learning and upbringing) and gives the right to a person to function successfully in a society. In a narrow sense, competence is analyzed as an activity characteristic, in other words, the degree of human involvement in activities that involves possession of the appropriate competence [1].

The future teacher of technology, economic education and upbringing should be based on such basic constituent principles of competence: science, communication with life, with the practice of creating the material goods, which forms the internal structure of competence.

Therefore, the task of education and training of the future teacher of technology becomes a strategic task that determines the state further development. The educational training and the professional competence formation of the future teacher of technology in the current conditions are related to the socio-economic problems of the society development, the development of competition, changes in the content of training, as well as the preparation and implementation of new programs, textbooks, which answer the requirements of a market economy.

The place and importance of economic education in the educational plans of educational institutions of all levels determine a number of reasons: first, the need to give the young generation initial knowledge of the essence, principles and purpose of economic activity of people in society, and secondly, to form a system of new generation of specialists in the national manage the economic knowledge, business efficiency, entrepreneurship, to teach to analyze the economic situation and make informed decisions, thirdly, to provide young people with the theoretical knowledge necessary for the management of production and economic processes.

The article substantiates that the economic education and excellent approaches to its mastering, as well as the use of Ukrainian normative documents, programs and standards are the main factors for the theoretical and methodological principles of forming the key competences for young people.

The decision of this case determines the processing and implementation of such a system of teaching the economic disciplines, which would ensure the compliance with the principles of continuity, consistency, systemcity, completeness. Based on these principles, the students can better understand the system of economic ties in action, from the childhood grasp the main economic concepts, and truthfully evaluate the causes and consequences of various social phenomena.

The knowledge of the fundamentals of economics positively affects the development of creativity, moral culture of the student, which helps in finding the ways of new studying or work, makes it possible to effectively use their perspectives in their interests and interests of society, which is very relevant during the formation of a young person as a citizen. The moral culture of future teachers of technology in economic awareness forms the general competence of the student, the ability to analyze and assess the economic situation, the ability to solve specific life problems [1].

The next changes, convinced, will be dictated by two factors: the growth of the single world economy and the right to choose the consumer. We must go (and realize) that the world today is not just the only gigantic electronics market, the automotive industry, financial services, etc., but also a single educational market. And in this educational market, the future teacher of technologies should not only have profound knowledge of the educational system, orientation in the latest technologies, but also be able to determine the anatomical, physiological, psychological, production-potential features of the pedagogical influence, which is also the subject of the pedagogical process. In other words, the teacher must be a physician of the human soul, able not only to put a scientifically grounded diagnosis, but also the art of his call and competence, together with the subject, parents, to design a road to the world of knowledge in such a way that "people around the world could participate in the best training courses conducted by the most famous teachers" [2].

The process of upbringing and shaping the moral culture of future teachers of technology is a multifactorial process: it affects the family, partial teachers, the whole system of lifelong education as a whole, a whole society with its educational institutions. It is determined that the heavier in its orientation and content the influences of the combined educational activities and unbiased conditions are focused, the formation of personality is more successful. The peculiarity of the educational process is manifested in the activity of the lecturer - the head of this process, which is conditioned not only by objective laws. His activities are mostly art in its nature, which testifies to the peculiarity of the personality of the teacher, his individuality and character.

Technology is the word of Greek origin, which originally means the knowledge about skill. The state-building processes that are taking place in Ukraine today cover all areas of life. The process of establishing a national school in Ukraine is characterized by the search for such pedagogical technologies that would maximally contribute to the formation of a socially active, creative person capable of selfregulation of one's own life. Particularly relevant is the problem of formation of a new high school, which is designed to form nationally conscious and spiritually rich professionalsteachers of technology, with a high level of culture, etiquette and tolerance, Professor O. Shpak notes in his works [3].

The concept "culture" in its common sense determines the special achievements of person in the mental and psychic spheres of the application of ones' forces. Therefore, the process of integration of the power of reason, the will of power, and the powers of the spirit becomes almost a priority task of the modern person. In this sense, the system-forming mechanisms of self-knowledge give the individual a universal opportunity to creative self-realization.

Thus, the formation of a moral culture in a competitive market economy requires the power of reason as a manifestation of the ability to form a culture of future teachers of technology, the development of intelligence and the development of a high level of professionalism, forming a general erudition of professional competencies. 
The economic knowledge of most graduates of schools has a theoretical character, detached from reality, and as a result, young people are not able to counteract the adverse events of a market economy. As the realities of the present indicate, a part of young people cannot be competitive in the labor market, due to a lack of practical skills, moral and ethical education, the level of culture of communication and business etiquette of labor activity.

The general goal of education and formation the moral culture of future teachers of technology is specified through a system of educational tasks, which are united in directions:

Intellectual (mental) education implies: assimilation of the knowledge system, which is designed from the corresponding education subjects and contains a list of semantic elements of social experience (facts, concepts, definitions, theorems, laws, regulations, rules, algorithms of activity); development of cognitive interest, creative activity, thinking, rational organization of education work; development of critical thinking, ability to realize and defend a personal position; development of the ability to independently acquire knowledge; readiness for application of knowledge, skills in practical activity; personal outlook formation it's a generalized understanding of the world as a whole on the basis of a large number of orderly views, beliefs, ideals.

Patriotic education: education of love for native land, family, people, the Motherland; formation of national consciousness; cultivation of the best features of the state mentality, hard work, individual freedom, deep connection with nature, etc; education of the attentive attitude to the national wealth of the country, language, culture, traditions; formation of readiness for creative work for the benefit of people, a feat in the name of prosperity of the state; formation of responsibility for the fate of the Motherland; education of civic duty towards the country by society; formation of political culture; development of ethics of interethnic relations.

Legal education: instilling respect for human and civil rights and freedoms;

education of respect for the Constitution, laws of Ukraine, state symbols (Emblem, Banner, Hymn); mastering the foundations of state, labor, civil, family and criminal law; formation of a deep awareness of the relationship between the ideas of freedom, human rights and its civil responsibility; education of respect for the rights and freedoms of other people; formation of active counteraction to cases of violation of laws.

Moral education: Formation in the students of the foundations of universal and folk morality: conscientiousness, decency, tact, compassion, mercy, kindness, honesty, humanity, tolerance and other charity; education of respect for parents, spiritual unity of generations; education of self-esteem: honor, freedom, equality, hard work, self-discipline; readiness to build their lives in accordance with the principles of humanism; cultivating a culture of behavior.

Artistic and aesthetic education: mastering the basics of folk art, music, architecture, oral folk art, national song and dance culture, everyday life, crafts, games; formation of a system of knowledge about world culture and art; development of aesthetic needs and feelings; development of artistic abilities and creative activity; readiness to build their own lives according to the laws of beauty.

Labor education: development of conscious attitude to work as the highest value of man and society; formation of labor skills and abilities; formation of the ability to work independently and effectively; development of the need for creative work; education of business efficiency, entrepreneurship; raising the sense of the owner and economic responsibility; the formation of readiness for work in a market economy.
Environmental education: formation of understanding the necessary harmony of man and nature; mastering the knowledge about the nature of land; raising the sense of responsibility for nature as national wealth, the basis of life on earth; formation of readiness for active ecological activity; forming the foundations of global economic thinking.

In the developed countries of the world, the purposeful education is the main direction of the activities of general education institutions, and moral, spiritual formation of personality - its most important tasks [4].

The upbringing of youth on the Christian basis of culture in the upbringing of youth in Ukrainian society, the author is disclosed in [5, 101-105]. The term "culture" has Latin origin (cultura - processing, development, and education) and initially meant the allocation of soil, its processing. Initially, under the culture understood all changes in the natural object, which took place under the influence of man. For the first time, the term culture originated in ancient Greece and was translated as educated. The whole world was divided into the educated and the ignorant. Everything that was found in Greece was considered cultural, and beyond it - that is a barbarian. Subsequently, the word culture received a generalized meaning and they began to call everything created by man. In this approach, culture is understood as created by man "second nature". Culture includes the results of material and spiritual production.

Culture - a specific way of organizing the development of human activity, discovered as a result of material and spiritual work, in the totality of human relations to nature, between themselves and to themselves.

It should be noted that the subject of cultural studies was developed by the authors Valentyna and Viktor Zdorovenko, where the authors cover the aspects that are characteristic of current graduates and argue that culture is oriented on the integration of all types and methods of human activity from the perspective of development, improvement of the person as a subject and at the same time object of this activity [6].

In the study, the author found that at the present stage it becomes increasingly obvious that the traditional school is focused on the transfer of knowledge, skills and abilities, does not keep up with the pace of their build-up. The modern school does not sufficiently develop the abilities needed by its graduates in order to self-identify themselves in the world, make informed decisions about their future, and be active and mobile in the labor market. The main disadvantages of the traditional system of education are its inability and unwillingness to constantly study young people, incompetence of a value relation to their own development and education [7].

As a result of studying the students, the future technology teachers in the educational and upbring directions should realize the communicative intent to convince adequately the task and conditions of communication; to ensure the coherence and integrity of the statement; give arguments and evidence, express their point of view.

Thus, the communicative competence of the future teacher is understood as the integral quality of the individual, which synthesizes the general culture of communication and its specific manifestations in the professional activity. It is precisely the means of a living convincing word that ensures the formation of the student's or the student's creative personality. The nature of the lecturer's activity, his style of communication, is one of the key to his professional influence on the subject of the educational process.

\section{Conclusions}

1. Each educated system is based on the values that determine the direction of the educational process: on the interests of society, state or personality (individual and personal devel- 
opment); on the relationship between the participants in the process (authoritarian or humanistic); on the content of the educational process - knowledge or developmental.

The success of the restructuring of the socioeconomic system depends primarily on the individual and its cultural potential, on the level of formation of socially significant, creative qualities of man, from their practical implementation in all spheres of management, production, science. Therefore, the further development of the domestic economy also depends to a large extent on the qualitative training of future teachers of technology, who must create the proper conditions for self-realization, the development of entrepreneurship and professional self-determination of students in order to socialize and adapt them in a modern, globalized world.

2. The moral culture of education involves excessive management of the educational process, according to which the future teachers purposefully master social tasks and ideologically oriented qualities; the regulation that comes to ignore the inner world of the individual.

3. The humanistic education system puts the personality of the future teacher of technology in the epicenter as the highest value of life. The formation of the moral culture of future teachers of technology involves not only the level of development of social properties of the individual, but also the upbringing of values, expressing the ideal of a person who, under all conditions, maintains true humanity.

Therefore, the further development of the domestic economy also depends to a large extent on the qualitative training of future teachers of technology, who must create the proper conditions for self-realization, the development of entrepreneurship and professional self-determination of students in order to socialize and adapt them in a modern, globalized world.

References

1. Vachevskiy M.V. The theoretical and methodical principles of formation the professional competence in future marketers [Monograph] M.V.Vachevskiy. - K.: Professional Publ., 2005. - 573 p.
2. Formation of vital economic competencies in educational activities. [Shpak O., Bulavenko S. Prymachenko N.] // Youth and market. - vol. 8 (163). P. 6-12

3. Interconnection between labor and economic education of students. Tutorial. I [Shpak O.T., Teres V.I., Uhlyarenko N.M.] - Drohobych: "Dimension", 2006. - 208 p.

4. Moral culture of managers. [Monograph for students of higher education institutions that are studying economic disciplines for the formation of professional competences for the labor market.] / [Andzhey Krynskiy, Dariush Senkevych, Nataliya Prymachenko]. - Drohobych-Chenstokhovo. Publishing house "Kolo", 2013. - 279 p.

5. Prymachenko N. The Christian Foundations of Culture in Education of Youth in Ukrainian Society. / N. Prymachenko // Youth and market. - 2007. Vol. 11-12 (34-35). - P. 101-105.

6. Zdorovenko V.V. Culture of business communication. Tutorial. V.V. Zdorovenko. - Drohobych, Kamenyar Scientific Center, 2002. - 147 p.

7. Vyshnevskiy O. I. The theoretical foundations of modern Ukrainian pedagogy. [A Guide for Students at Higher Educational Institutions.] / O.I. Vyshnevskiy O. I. - Drohobych, "Kolo", 2006. - 608 p.

Список використаних джерел

1. Вачевський М.В. Теоретико-методичні засади формування у майбутніх маркетологів професійної компетенції: Монографія - К.: ВД “Професіонал", 2005. - 573 с.

2. Шпак О., Булавенко С., Примаченко Н.(2018). Формування життєво важливих економічних компетентностей у навчальній діяльності. // Молодь і ринок. - 2018. - № 8(163), С.6-12

3. Шпак О.Т., Терес В.І. Угляренко Н.М. Взаємозв'язок трудового і економічного виховання учнів. Навчальний посібник. Дрогобич: "Вимір". 2006. -208 c.

4. Анджей Криньські, Даріуш Сенкевич, Наталія Примаченко. Моральна культура менеджерів. Монографія для студентів вищих навчальних закладів, які вивчають економічні дисципліни для формування професійних компетенцій для ринку праці. Дрогобич-Ченстохово. Видавництво “Коло”, 2013. - 279 с. (Видання друге, перероблено і доповнено).

5. Примаченко Н. Християнські засади культури у виховані молоді в українському суспільстві. // Молодь і ринок. -2007. - № 11-12 (34-35). C101-105.

6. Здоровенко В.В.(2002). Культура ділового спілкування. Навчальний посібник. Дрогобич, - НВЦ “Каменяр”, 2002. - 147с

7. Вишневський О.І. (2006). Теоретичні основи сучасної української педагогіки. Посібник для студентів вищих навчальних закладів. Дрогобич, "Коло", 2006. - 608 с.

Надійшла до редколегії 11.04.19

І. Зварич, док. пед. наук

Київський національний торговельно-економічний університет, Київ, Україна

Н. Примаченко, канд. пед. наук

Дрогобицький державний педагогічний університет імені Івана Франка, Дрогобич, Україна

І. Ромащенко, канд. пед. наук, доц.

Національний університет імені Таврія Володимира Вернадського, Київ, Україна

\section{МАЙБУТНІЙ ВЧИТЕЛЬ ТЕХНОЛОГІЙ - МОРАЛЬНО-КУЛЬТУРНА ОСОБИСТІСТЬ В ОСВІТНЬО-ВИХОВНИХ НАПРЯМКАХ ОСВІТИ}

Висвітлено основні ідей та принципи досліджуваної проблеми; окресленні основні професійні здібності і компетенції та впровадження методичного забезпечення в навчальний процес, що сприяє ефективному формуванню моральної культури у майбутніх вчителів технологій. Як вважають провідні вчені, орієнтація вищої школи на сучасний і навіть випереджаючий рівень розвитку суспільновиробничих відносин у підготовці фахівця можлива лише за умови вивчення цих вимог, через дослідження діяльності цього фахівця. Пошук вдосконалення професійної підготовки майбутнього вчителя - проблема, актуальність якої обумовлена тенденцією вимог до професійної діяльності вчителя.

Сучасна освіта України спрямована на надання учням необхідних знань, вироблення умінь і навичок. За період навчання майбутній вчитель має подати багато фактичного матеріалу. В досліджені висвітлюються економічні знання більшості випускників шкіл які мають теоретизований характер, відірваний від реальної дійсності, унаслідок чого молоді люди не можуть протистояти негативним явищам ринкової економіки. Про це свідчать реалії сьогодення, частина молоді не може бути конкурентоздатною на ринку праці, з причин нестачі практичних навичок, морально-етичного виховання, рівня культури спілкування та ділового етикету трудової діяльності. 3 метою розв'язання цих завдань здійснюється активне впровадження у навчальний процес навчальних закладів, зокрема педагогічних, дисциплін економічного спрямування. Досліджено, сучасна школа потребує вчителів технологій з широким світоглядом, які володіють не лише системою інтегрованих знань технологічного, психолого-педагогічного, методичного характеру, а й глибоким економічним мисленням. Заклади вищої освіти створюючи культурний потенціал особистості, покликані визначати спосіб їі самореалізації, суб'єктивний зміст її продуктивної діяльності. Залежність рівня сформованості і особливостей культури особистості можуть мінятися в конкретних видах і сферах соціального життя. На кожному етапі соціального розвитку, у тому числі і формування ї̈ культури, є передумовою продуктивного функціонування суспільства.

Ключові слова: морально-культурна особистість, виховний процес, технології, сучасна школа, керівник, культура, економічна освіта, професійна компетентність, компетенція, професійне спілкування. 